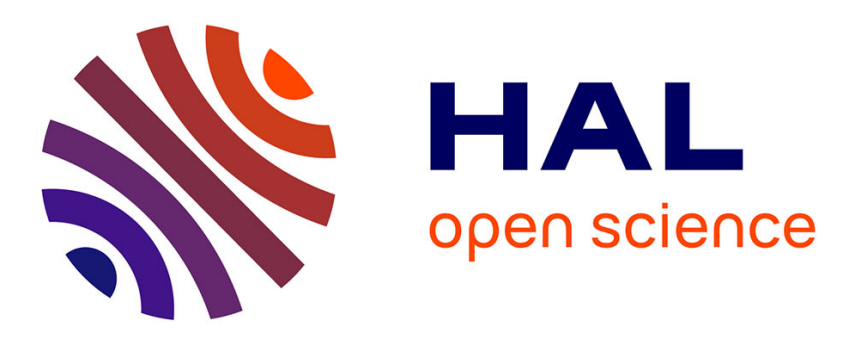

\title{
Daily apportionment of stranded plastic debris in the Bintan Coastal area, Indonesia
}

\author{
Agung Dhamar Syakti, Maxime Jacob, Timothee Birrien, Mario Putra \\ Suhana, Muhammad Yudistira Aziz, Agus Salim, Pierre Doumenq, Guy \\ Louarn
}

\section{To cite this version:}

Agung Dhamar Syakti, Maxime Jacob, Timothee Birrien, Mario Putra Suhana, Muhammad Yudistira Aziz, et al.. Daily apportionment of stranded plastic debris in the Bintan Coastal area, Indonesia. Marine Pollution Bulletin, 2019, 149, pp.110609. 10.1016/j.marpolbul.2019.110609 . hal-02438184

\author{
HAL Id: hal-02438184 \\ https://hal.science/hal-02438184
}

Submitted on 14 Feb 2020

HAL is a multi-disciplinary open access archive for the deposit and dissemination of scientific research documents, whether they are published or not. The documents may come from teaching and research institutions in France or abroad, or from public or private research centers.
L'archive ouverte pluridisciplinaire HAL, est destinée au dépôt et à la diffusion de documents scientifiques de niveau recherche, publiés ou non, émanant des établissements d'enseignement et de recherche français ou étrangers, des laboratoires publics ou privés. 


\title{
Daily apportionment of stranded plastic debris in the Bintan Coastal area, Indonesia
}

\author{
Agung Dhamar Syakti ${ }^{\mathrm{a}, \mathrm{b}, *}$, Maxime Jacob ${ }^{\mathrm{c}}$, Timothee Birrien ${ }^{\mathrm{c}}$, Mario Putra Suhana ${ }^{\mathrm{a}}$, \\ Muhammad Yudistira Aziz ${ }^{\mathrm{d}}$, Agus Salim ${ }^{\mathrm{e}}$, Pierre Doumenq ${ }^{\mathrm{f}}$, Guy Louarn ${ }^{\mathrm{c}}$ \\ ${ }^{a}$ Marine Science and Fisheries Faculty - Raja Ali Haji Maritime University, Jl. Politeknik Senggarang-Tanjungpinang, Riau Islands Province, 29100, Indonesia

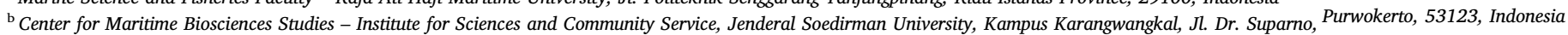 \\ ${ }^{\mathrm{c}}$ University of Nantes, Polytech, IMN - CNRS, UMR 6502, 44322, Nantes, France \\ ${ }^{\mathrm{d}}$ Faculty of Mathematic and Natural Sciences, Institut Teknologi Bandung. Jl. Ganesha No. 10 Bandung, 40133, Indonesia \\ ${ }^{\mathrm{e}}$ Science and Technology Faculty- Jakarta Islamic State University (UIN), Ciputat, Jakarta. Jl. Ir. H. Juanda No. 95 Ciputat, Tangerang, Selatan, 15412, Indonesia \\ ${ }^{\mathrm{f}}$ Aix Marseille Université, CNRS, LCE, UMR 7376, 13545, Aix-en-Provence Cedex 4, France
}

${ }^{*}$ Corresponding author. Marine Science and Fisheries Faculty - Raja Ali Haji Maritime University, Jl. Politeknik Senggarang-Tanjungpinang, Riau Islands Province, 29100, Indonesia.

E-mail address: agungsyakti@chemist.com (A.D. Syakti).

\section{A B S TR A C T}

This study aims to provide a baseline report of the apportionment of stranded plastic debris (macro) in Bintan Island beaches. Their quantity and composition were assessed during a 45-day survey demonstrating the oc-currence of the 3378 plastic fragments, which were, in decreasing order, constituted by LDPE (22.9\%), PS (19.5\%), PP (16.6\%), PET (10.4\%), HDPE (9.2\%), PVC (7.2\%), PU (4.9\%), polyester (4.7\%), polyamide (4.3\%), and styrene/butadiene (0.3\%). The abundance ranged from 1.2 to $4.7 \mathrm{items} / \mathrm{m}^{2}$. Additional apportionment ranged from 0.03 to $0.15 \mathrm{items} / \mathrm{m}^{2}$ per day with an arithmetic mean of $0.09 \pm 0.05 \mathrm{items} / \mathrm{m}^{2}$ per day, mainly related to domestic waste influenced by hydrodynamic action such as longshore current and wind dynamics. Furthermore, we suggested mitigation measures focused on local action to address the plastic debris problem in Bintan beaches, which are typical of the coasts of small islands in Indonesia.

Since 2015, plastic pollution has attracted public attention in Indonesia. After being declared as the second largest plastic contributor to the marine environment (Jambeck et al., 2015), through public in-formation dissemination acts, i.e., conferences, seminars, and commu-nity action, all related stakeholders (academia, business sector, com-munity, government, and media) enforced their roles to solve the claimed problem. However, the Indonesian Government has stipulated recent regulations through Presidential Decree No. 83 concerning waste handling in the sea, which constituted the national action plan to re-ducing $70 \%$ of marine plastic in the marine environment by the year 2025 (Perpres 83/2018). Nevertheless, the real data to contradict Jambeck's model are still lacking in Indonesia. Limited studies have been conducted by Indonesian scientists. Marine contamination with plastic debris has been reported in the Indonesian area by several au-thors. For instance, Syakti et al. $(2017,2018)$ reported the occurrence of macroplastics and floating microplastics in the southern part of Java in the adjacent Indian Ocean and the Bintan area. Cordova et al. (2018) reported the presence of microplastics in coral reef sediment in Lombok and in the deep sea of the southwestern Sumatra coast (Cordoba and Wahyudi, 2016). Recent studies were also conducted on the occurrence of microplastics in biota (Rochman et al. 2015; Lubis et al., 2019) and the absorbed co-pollutants, i.e., PAHs and PCBs (Bouhroum et al. 2019), as well as the impact of microplastics (Syakti et al. 2019). The present study investigated the apportionment of stranded plastic debris (macro) on Bintan Island (Fig. 1), an area in Indonesia that is close to the Ma-lacca and Singapore Straits, which is recognized as the most crowded sea-lane and a maritime traffic zone and could potentially experience a sea-based leakage of plastic from ship lines. Seven sites with different orientations and nearby activity were studied around Bintan and were classified as touristic (S1-S4), in-dustrial (S5), and domestic (S6) harbors and/or as for industrial ac-tivities. For each station, a $180 \mathrm{~m} 2$ permanent quadrat $(6 \times 30 \mathrm{~m})$ was designed in the intertidal zone, and the plastic items were then en-umerated. The polymers were also identified directly on site using a Mobil-IR Portable FTIR Spectrometer (Bruker Optik $\mathrm{GmbH}$, Germany) with Bruker OPUS software. Each site was visited at least three times during a period of 45 days, with a minimum waiting time of 7 days between each visit. The stranded plastics occurring from several pro-ducts such as fishing nets, ropes, bottles, plastic cups, plastic bags, straws, rubber items, sandals, and lighters were analyzed using the Mobil-IR Portable FTIR system. We conducted 10-15 analyses for each of the found products, and the remaining products with the same/si-milar visual perception could be directly counted as the same specific polymer. We completed at least $250-300$ analyses with the FTIR system. Next, to assess the impact of weathering on plastic, a seabed inspection for sunken debris was performed to compare the different aging conditions of the sunken PET as a polymer model. PET was chosen because of its easy identification through visual inspection be-fore confirmation by FTIR and its stability under outdoor light (Summers and Rabinovitch, 1999). PET samples were visually ana-lyzed, and some samples were removed for further FTIR analysis. Twodimensional hydrodynamic models were conducted using MIKE 21 software with the mesh generator module to estimate the boundary conditions limiting the open and enclosed areas of the model (Salim et al., 2016). Wind data were obtained from the European Centre for Medium Range Weather Forecast (ECMWF), which was subsequently extracted using Ocean Data View software to obtain zonal and mer-idional wind components. Data were then converted to obtain the direction and wind speed values simulating the current hydrodynamic model for August 1, 2018.

To assess the baseline level, from the $180 \mathrm{~m} 2$ area at each permanent sampling point, we found that the plastic debris number ranged from 214 to 842 items (1.2 items $/ \mathrm{m} 2-4.7$ items $/ \mathrm{m} 2)$. The highest number was at station S6 (842 items), followed by stations S4 (533 items) and S7 (511 items) (Table 1). Three other stations that shared the same large magnitude were S1 (457 items), S5 (411 items), and S3 (398 items). The cleanest station was S2 (214 items).

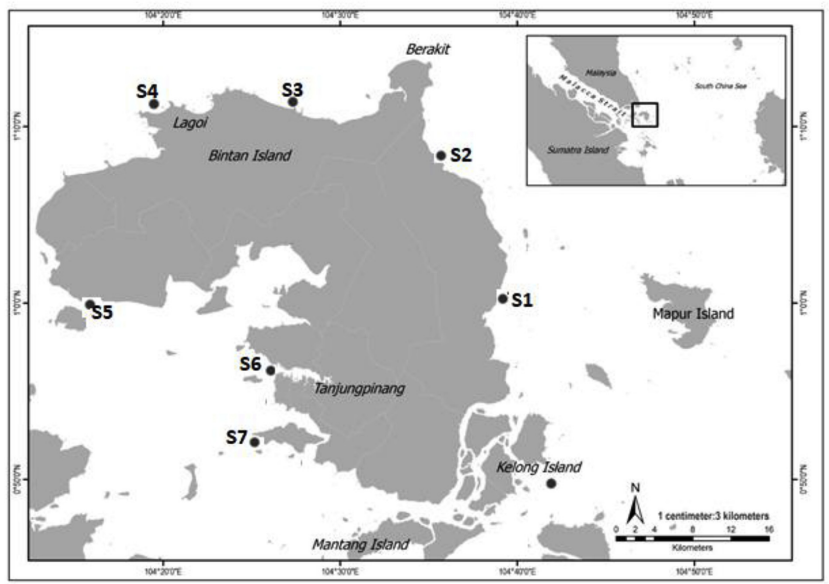

Fig. 1. Sampling sites in the coast of Bintan, Indonesia. 
Table 1

Baseline of plastic debris level and polymer identification in Bintan beaches.

\begin{tabular}{|c|c|c|c|c|c|c|c|}
\hline \multirow[t]{2}{*}{ Debris polymers } & \multicolumn{7}{|l|}{ Sites } \\
\hline & S1 & S2 & S3 & S4 & S5 & S6 & S7 \\
\hline LDPE & 101 & 5 & 20 & 22 & 71 & 361 & 193 \\
\hline $\mathrm{PP}$ & 45 & 39 & 55 & 97 & 49 & 197 & 80 \\
\hline Polyester & 17 & 31 & 11 & 27 & 25 & 41 & 8 \\
\hline Polyamide & 12 & 30 & 10 & 27 & 24 & 35 & 8 \\
\hline PET & 52 & 37 & 116 & 87 & 40 & 7 & 11 \\
\hline HDPE & 39 & 14 & 52 & 109 & 38 & 21 & 38 \\
\hline PS & 144 & 21 & 59 & 62 & 132 & 85 & 157 \\
\hline PVC & 28 & 30 & 47 & 98 & 16 & 15 & 11 \\
\hline PU & 16 & 5 & 17 & 27 & 16 & 77 & 6 \\
\hline Styrene/Butadiene & 4 & 1 & 2 & 0 & 0 & 4 & 0 \\
\hline Total & 457 & 214 & 389 & 533 & 411 & 842 & 511 \\
\hline
\end{tabular}

Table 2

Comparison of the abundance of stranded plastics relative to that in other coastal areas worldwide.

\begin{tabular}{lll}
\hline Region & [items $\left./ \mathrm{m}^{2}\right]$ & Reference \\
\hline Bintan coast (Indonesia) & $1.2-4.7$ & This study \\
Mediterranean (Western) & $0.2-6.9$ & Asensio-Montesinos et al. (2019) \\
Cape Town, South Africa & $0.2-24.5$ & Chitaka and von Blottnitz (2019) \\
Northwestern Mediterranean & $92-4653$ & Constant et al. (2019) \\
Sri Lanka beaches & $4.1-158$ & Jang et al. (2018) \\
Luzon beach, Philippines & 0.7 & Paler et al. (2019) \\
Guandong coast, China & $3-347$ & Fok et al. (2017) \\
Korea beaches & $0-44$ & Lee et al. (2017) \\
Cilacap coast, Indonesia & $16.8-41.6$ & Syakti et al. (2017) \\
South China Sea & $3-347$ & Zhao et al. (2015) \\
Hawaiian Archipelago & $4-17,645$ & McDermid and McMullen (2004) \\
Portugal coast & $29-393$ & Martin and Sobral (2011)
\end{tabular}

As shown in Table 2, the amount of stranded plastic found on Bintan beaches was the same as that of the macroplastics found in the western part of Mediterranean, i.e., the amount of stranded plastic found on Bintan beaches. An amount of 0.2-6.9 items per m2 (Asensio-Montesinos et al., 2019) can be classified as extremely dirty according to Alkalay et al. (2017) and Paler et al. (2019), but in terms of accu-mulation, it was less polluted than the plastic debris in Cape Town (Chitaka and von Blottnitz, 2019) and the Northwestern Mediterranean (Constant et al., 2019). Table 2 shows the results of stranded plastics from different studies for clear comparison with our study results.

Using the portable FTIR, we directly analyzed plastics from 3378 plastic fragments among the stranded litter on the Bintan coast. We bserved that low-density polyethylene (LDPE), polystyrene (PS), polypropylene (PP), polyethylene terephthalate (PET), and high-density polyethylene (HDPE) were indeed in the top 5 (Fig. 2), comprising 22.9\%, 19.5\%, 16.6\%, 10.4\%, and 9.2\% of the total stranded plastics, respectively. This result was comparable with the quantities of world's plastic demand by type in 2015, i.e., PP, LDPE, HDPE, polyvinyl chlorid (PVC), and polyurethane, respectively (PlasticEurope, 2017).

For instance, the quantity of PS in Bintan was much higher than its production percentage worldwide, which might reflect its common usage. The amount of PS may be due to fishing activities on nearby coasts and from the wide consumption of single-use cutlery and packaging for takeaway food. The PET stranded on Bintan was even more visible, but the explanation was simple: as plastic bottles travel longer distances in the ocean, an isolated island such as Bintan is likely to receive more.

The average percentage of plastic items found is shown in Table 2 where S6 was still the most contaminated station by approximately 4.7 items $/ \mathrm{m}^{2}$, while the cleanest station $\mathrm{S} 2$ had 1.2 item $/ \mathrm{m}^{2}$.

\section{Additional apportionment}

We calculated the arithmetic mean of the number of items $/ \mathrm{m} 2$ during the 45 days of observation (Table 3 ). The additional appor-tionment was $1.3-6.4$ items $/ \mathrm{m} 2$, and during the observation for 30-48 days, we estimated that the apportionment rates ranged from 0.03 to 0.15 items $/ \mathrm{m} 2$ per day, with an arithmetic mean of $0.09 \pm 0.05$ items $/ \mathrm{m} 2$ per day, depending on the studied sites. The largest amount of newly stranded plastic was found in S6, showing an average of 6.4 items $/ \mathrm{m} 2$ and 27.6 items per day with an apportionment rate of 0.15 items $/ \mathrm{m} 2$ per day. We suggest that this result can be related directly to the large population living close to the Tanjung Pinang City, which is the capital of the Riau Islands. Another meaningful contamination of plastics on the Bintan coast was found in S1 (4.2 items $/ \mathrm{m} 2$ and 25.3 items/day) and S4 (4.0 items/m2 and 22.0 items/day), which are tourist sites with many pleasant activities. Both have a similar daily apportionment that reaches 0.14 items $/ \mathrm{m} 2$ per day (S1) and 0.12 items $/ \mathrm{m} 2$ per day (S4). S7 and S5 shared the same large magnitude, with 15.6 and 12.6 items/ $\mathrm{m} 2$ and 4.4 and 3.4 additional items/day, respectively. Their rates were $0.07 \mathrm{items} / \mathrm{m} 2$ per day (S5) and 0.09 items/m2 per day (S7), respectively. Two other sites (S2 and S3) had a lower number of additional items per m2, ranging from 1.3 to 2.7 and 5.3 to 9.9 plastic items per day, respectively. Their daily apportionment rates were 0.03 items $/ \mathrm{m} 2$ per day (S2) and 0.05 items $/ \mathrm{m} 2$ per day (S3). Such conditions can be attributed to a variety of factors including currents and semidiurnal tidal patterns on the Bintan coast (Suhana et al., 2018). Pre-vious studies have investigated the influence of wind, waves, tides, seasonal patterns, and upwelling on the spatial distribution of floating plastic debris (Browne, 2010; Pereiro et al., 2019).

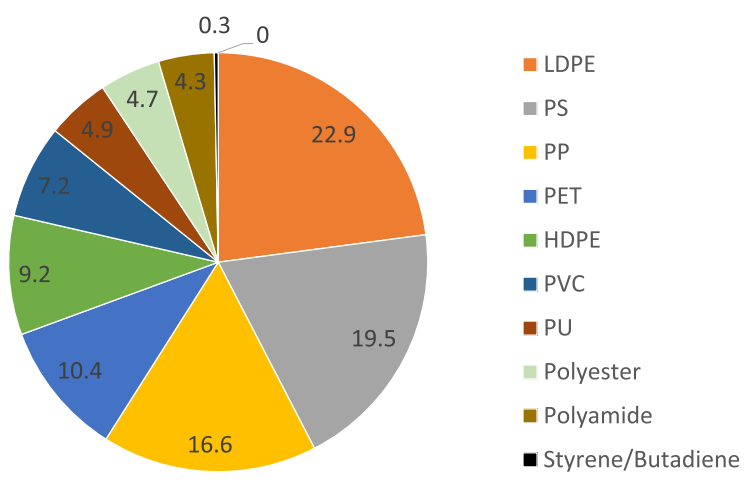

Fig. 2. Plastic polymers found in Bintan beaches. *the black part represents styrene/ butadiene, representing $0.3 \%$. 
Table 3

Dominant plastics stranded on the Bintan coast.

\begin{tabular}{|c|c|c|c|c|c|}
\hline \multirow[t]{2}{*}{ Site location } & \multirow{2}{*}{$\begin{array}{l}\text { Baseline } \\
\left(\text { items } / \mathrm{m}^{2}\right)\end{array}$} & \multicolumn{3}{|c|}{ Additional plastic debris (30-48 days) } & \multirow{2}{*}{$\begin{array}{c}\text { Dominant } \\
\text {-plastic type }\end{array}$} \\
\hline & & (items $/ \mathrm{m}^{2}$ ) & (items/day) & $\begin{array}{l}\text { (items/ } \\
\mathrm{m}^{2} / \text { day) }\end{array}$ & \\
\hline S1 & 2.5 & 4.2 & 25.3 & 0.14 & $\begin{array}{l}\text { PS, LDPE, } \\
\text { PET }\end{array}$ \\
\hline S2 & 1.2 & 1.3 & 5.3 & 0.03 & $\begin{array}{l}\text { PP, PET, } \\
\text { Polyester }\end{array}$ \\
\hline S3 & 2.2 & 2.7 & 9.3 & 0.05 & PET, PS, PP \\
\hline S4 & 3 & 4.0 & 22.0 & 0.12 & $\begin{array}{l}\text { HDPE, PVC, } \\
\text { PP }\end{array}$ \\
\hline S5 & 2.3 & 3.4 & 12.6 & 0.07 & PS, LDPE, PP \\
\hline S6 & 4.7 & 6.4 & 27.6 & 0.15 & LDPE, PP, PS \\
\hline S7 & 2.8 & 4.4 & 15.6 & 0.09 & LDPE, PS, PP \\
\hline
\end{tabular}

Most of the plastic debris encountered was predominantly from domestic use. As the site is surrounded by coastal houses and markets, most plastic comes from the nearby lands rather than from the sea. One of the supporting hypotheses to confirm this argument was the pre-dominance of LDPE found in this study, which is primarily recognized through visual inspection as a domestic use product.

There was a slight difference for the S4 and S1 sites, which are private resort areas that, regardless of their orientation, are less prone to plastic pollution. This finding may be due to beach clean-ups on the nearby beaches, which halt debris from blowing into our site. Interestingly, with regard to S2 and S3, most plastics probably come from the sea because human activity in this area is less frequent. We noted in this site that PET was the most abundant, followed by PP, PS, and polyester. Therefore, we can assume that bottles made of PET ar-rived through sea-based circulation from longer distances in the sea. In addition, the bulk of PS can be attributed to the food industry because it is associated with household packaging.

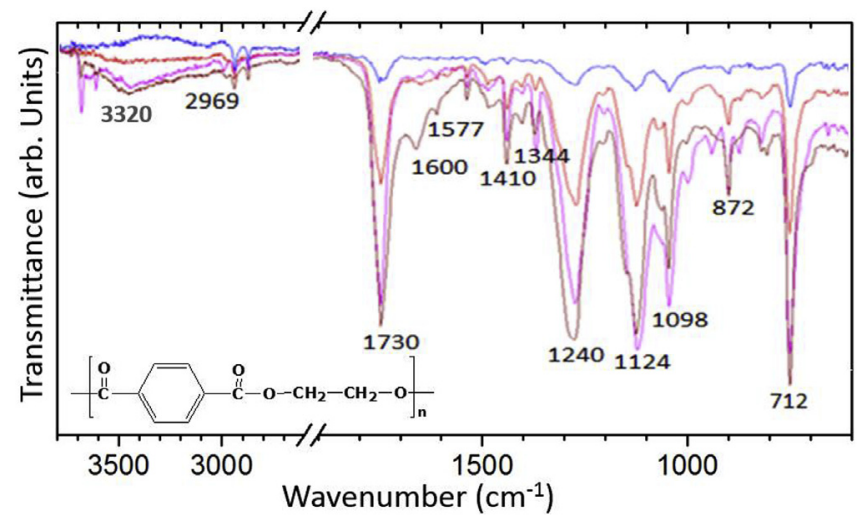

Fig. 3. Observable PET characterization. The colors represent different ages. Brown $=$ recent release, violet $=$ low aging, Blue $=$ somewhat degraded, Red = degraded. (For interpretation of the references to color in this figure legend, the reader is referred to the Web version of this article.)

\section{PET bottles found in the ecovillage remote beach}

In the EV, which is the most remote beach and is far from rural areas, we would expect the stranded plastic to be apportioned from the sea. At this station, PET was the most important; therefore, in this baseline, we focused our particular interest on PET apportionment and aging levels. We analyzed the different spectra from PET bottles with varying exposure times on the beach. The bottles were chosen by their appearance.

All collected data correspond to a PET spectrum. PET is recognized by the presence of a carbonyl group in conjugation with an aromatic ring at $1730 \mathrm{~cm}^{-1}$.

Two strong peaks at $1240 \mathrm{~cm}^{-1}$ and $1124 \mathrm{~cm}^{-1}$ were attributed to the terephthalate group (OOCC $6 \mathrm{H} 4-\mathrm{OOC}$ ) in the polymer. They are usually assigned to the $\mathrm{C}(=\mathrm{O})-\mathrm{O}$ and $\mathrm{C}-\mathrm{O}$ stretching vibrations of the ester function. The presence of the characteristic bands at $1344 \mathrm{~cm}^{-1}$ corresponded to the wagging mode of ethylene units (Duchesne et al., 2002).

Other bands reported in this study were the peaks at 2969 and $2909 \mathrm{~cm}^{-1}\left(\mathrm{CH}_{2}\right.$ stretching), $1577 \mathrm{~cm}^{-1}$ (aromatic C-C stretching), and $1410 \mathrm{~cm}-1(\mathrm{C}-\mathrm{H}$ bending from the ethylene group). Finally, aromatic $\mathrm{C}-\mathrm{H}$ wagging also appeared at $872 \mathrm{~cm}-1$ and $712 \mathrm{~cm}-1$ and was assigned to $\mathrm{CH}$ out-of-plane bending.

Aging degradation is not apparent owing to infrared absorption. Fig. 3 shows the presence of a large band at approximately $3320 \mathrm{~cm}-1$. This band is probably due to the contamination of the plastics by or-ganic contaminants or live species. We can also assume that the pre-sence of this band is the signature of the beginning of PET hydrolysis after an extended time in the sea and under natural UV light. We should stress the presence of 2 unusual thin bands at approximately $3432 \mathrm{~cm}-1$. The presence of these bands is unclear and most likely deserves more attention in future studies. There were no other visible changes in the four different PET spectra. Unsurprisingly, this finding is probably due to the very high stability of PET with time in the natural environment.

Fig. 4 shows that the current patterns in the coastal Bintan waters were predominantly moving north and northeast (Fig. 4A). The current pattern of motion was estimated following the shape of the island, with an overall current speed ranging between 0.05 and $0.32 \mathrm{~m} / \mathrm{s}$ (Fig. 4C). Additionally, the wind speed ranged predominantly from 5.5 to $5.8 \mathrm{~m} / \mathrm{s}$ in the southern part (Fig. 4B). This phenomenon supports our finding that S4, S5, S6, and S7 were the worst beaches in terms of litter content and abundance due to land-based input and concomitant apportion-ment from the sea, partially from the west-southwest part of island through the current and through the wind from the south. In general, Bintan beaches are largely affected by the plastic debris issued by human activities related to coastal use and hydrodynamic action, such as the longshore current and the wind speed and direction. 
[m]
A

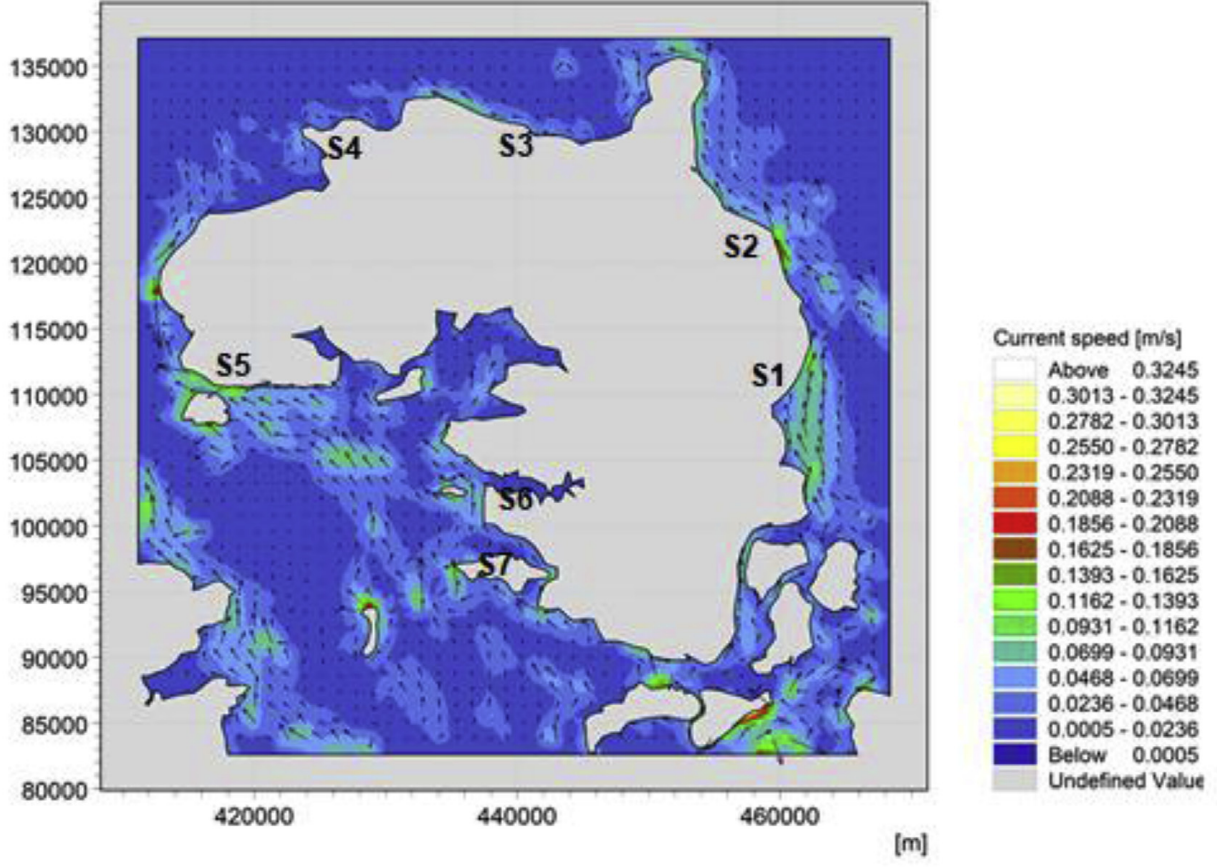

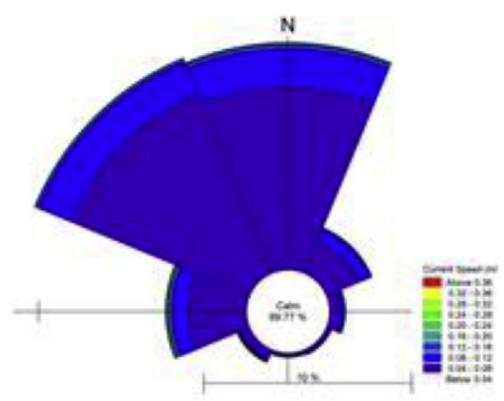

C

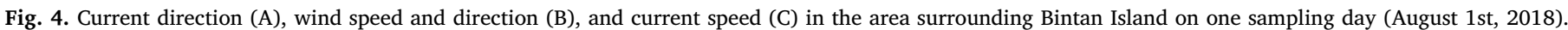

Because the government of the province of the Riau Islands relies on tourism and fisheries as the leading sector to increase the regional domestic product, a very good quality and healthy marine environment, free from plastic waste, should be maintained in Bintan, Riau Islands. Thus, environmental authorities should focus more attention on strengthening the institutional arrangement among penta-helix stake-holders, i.e., academia, the business sector, the government, and the community including NGOs and the media, to prevent beach pollution and to promote high-quality tourism at the national and regional levels through integrated approaches to plastic waste management. For in-stance, as suggested by several authors (Zielinski et al., 2019), a beach management strategy should be based on both land-based and sea-based leakage reduction. To recall the political commitment, we pro-posed several recommendations as follows: (i) increase public aware-ness through media information, such as local television, newspapers, and social media including websites; (ii) enforce paid plastic usage; (iii) reduce the use of single-use plastics in formal government activities;(iv) speed up efforts to clean the beach of existing plastic waste with a focus on plastic waste hotspots (e.g., stations S6 and S7); (v) improve our understanding of the plastic waste problems by financing research; and (vi) encourage and facilitate the regional mechanism (ASEAN countries) for marine debris surveillance at the ASEAN level, including tracking, monitoring, reporting, and law enforcement mechanisms.

\section{Acknowledgments}

The authors are thankful for the financial support of Demand-Driven Research Grant (DDRG) from Coral Reef Rehabilitation and Management Project-Coral Triangle Initiative (COREMAP-CTI) No.: B-1968/IPK.02/KS/III/2018 and from Kemristekdikti for PKLN Grant No. 1968/UN23.14/ PN/2018. Dr. Syakti's special thanks are dedicated to his students who participated during this study (Suteri, Dea, Anggie, Liya, Tital, Reni, and Iqbal) from the Marine Science and Aquatic Resources Department, Raja Ali Haji Maritime University. The authors thank the anonymous reviewers and Bruce J. Richardson, Ph.D (Baseline Editor) for their constructive comments and helpful sugges-tions. 


\section{References}

Alkalay, R., Pasternak, G., Zask, A., 2007. Clean-coast index-a new approach for beach cleanliness assessment. Ocean Coast Manag. 50 (5-6), 352-362.

Asensio-Montesinos, F., Anfuso, G., Williams, A.T., 2019. Beach litter distribution alongthe western Mediterranean coast of Spain. Mar. Pollut. Bull. 1 119-12. Bouhroum, R., Boulkamh, A., Asia, L., Lebarillier, S., Ter Halle, A., Syakti, A.D., Doumenq, P., Malleret, L., Wong-Wah-Chung, P., 2019. Concentrations and finger-prints of PAHs and PCBs adsorbed onto marine plastic debris from the Indonesian Cilacap coast and the North Atlantic gyre. Reg. Stud. Mar. Sci. 29100611.

Browne, M.A., 2010. Spatial Patterns of Plastic Debris along Estuarine Shorelines Spatial

Patterns of Plastic Debris along Estuarine Shorelines. vol. 44. pp. 3404-3409. Chitaka, T.Y., von Blottnitz, H., 2019. Accumulation and characteristics of plastic debris

along five beaches in Cape Town. Mar. Pollut. Bull. 138, 451-457.

Constant, M., Kerhervé, P., Mino-Vercellio-Verollet, M., Dumontier, M., Sànchez Vidal, A.,

Canals, M., Heussner, S., 2019. Beached microplastics in the northwestern medi-

terranean sea. Mar. Pollut. Bull. 142, 263-273.

Cordova, M.R., Hadi, T.A., Prayudha, B., 2018. Occurrence and abundance of micro-plastics in coral reef sediment : a case study in Sekotong, Lombok-Indonesia. Adv. Environ. Sci. Bioflux 10, 23-29.

Cordoba, M.R., Wahyudi, A.J., 2016. Microplastic in the deep-sea sediment of south-

western Sumatera waters. Mar. Res. Indones. 41 (1), 27-35.

Duchesne, C., Kong, X., Brisson, J., Pézolet, M., Prud'homme, R.E., 2002. Molecular or-

ientation and relaxation of poly(ethylene terephthalate) by polarization modulation infrared spectroscopy. Macromolecules $35,8769-8773$.

Fok, L., Cheung, C.K., Tang, G., Li, W.C., 2017. Size distribution of stranded small plastic

debris on the coast of Guangdong, South China. Environ. Pollu. 220 (A), 407-412. Jambeck, J.R., Geyer, R., Wilcox, C., Siegler, T.R., Perryman, M., Andrady, A., Narayan,

R., Law, K.L., 2015. Plastic waste inputs from land into the ocean. Science 347 ,

768-771.

Jang, Y.C., Ranatunga, R.R.M.K.P., Mok, J.Y., Kim, K.S., Hong, S.Y., Choi, Y.R., Gunasekara, A.J.M., 2018. Composition and abundance of marine debris stranded on the beaches of Sri Lanka: results from the first island-wide survey. Mar. Pollut. Bull. 128, 126-131.

Lee, J., Lee, J., Hong, S., Hong, S.H., Shim, W.J., Eo, S., 2017. Characteristics of meso-sized plastic marine debris on 20 beaches in Korea. Mar. Pollut. Bull. 123 (1-2),92-96.

Lubis, I.E.N., Melani, W.R., Syakti, A.D., 2019. Plastic debris contamination in grey-eelcatfish (Plotosus canius) in tanjungpinang water, Riau islands-Indonesia. AIP Conf. Proc. 2094, 020035.

Martin, J., Sobral, P., 2011. Plastic marine debris on the Portuguese coastline: a matter of

size? Mar. Pollut. Bull. 62 (12), 2649-2653.

McDermid, K.J., McMullen, T.L., 2004. Quantitative analysis of small-plastic debris on

beaches in the Hawaiian archipelago. Mar. Pollut. Bull. 48 (7-8), 790-794.

Paler, M.K.O., Malenab, M.C.T., Maralit, J.R., Nacorda, H.M., 2019. Plastic waste oc-

currence on a beach off southwestern Luzon, Philippines. Mar. Pollut. Bull. 141,

416-419.

Pereiro, D., Souto, C., Gago, J., 2019. Dynamics of floating marine debris in the northern

Iberian waters: a model approach. J. Sea Res. 141, 57-66.

Perpres 83/2018., 2018. Peraturan Presiden Republik Indonesia No. 83 Tahun 2018

Tentang Penanganan Sampah di Laut.

PlasticEurope, 2017. Plastics - the Facts 2017 : an Analysis of European Plastics

Production, Demand and Waste Data. PlasticsEurope, Brussels, Belgium.

Rochman, C.M., Tahir, A., Williams, S.L., Baxa, D.V., Lam, R., Miller, J.T., Teh, F.C.,Werorilangi, S., Teh, S.J., 2015. Anthropogenic debris in seafood: plastic debris and fibers from textiles in fish and bivalves sold for human consumption. Sci. Rep. 514340.

Salim, A., Syakti, A.D., Purwandani, A., Sulaiman, A., 2016. On the dynamics of Oil spill

dispersion of Timor Sea. Int. J. Appl. Environ. Sci. 11 (4), 1077-1090.

Suhana, M.P., Nurjaya, I.W., Natih, N.M.N., 2018. Patterns and tidal characteristics of

east coast of Bintan Island, Riau Archipelago province. J. Appl. Geospatial Inf. 2,

98-101.

Summers, J.W., Rabinovitch, E.B., 1999. Weatherability of Vinyl and Other Plastics.

Weathering of Plastics. pp. 61-68.

Syakti, A.D., Bouhroum, R., Hidayati, N.V., Koenawan, C.J., Boulkamh, A., Sulistyo, I.,Salim, A., Syakti, A.D., Purwandani, A., Sulaiman, A., 2016. On the dynamics of Oil spill dispersion of Timor Sea. Int. J. Appl. Environ. Sci. 11 (4), 1077-1090.

Suhana, M.P., Nurjaya, I.W., Natih, N.M.N., 2018. Patterns and tidal characteristics of

east coast of Bintan Island, Riau Archipelago province. J. Appl. Geospatial Inf. 2,

98-101.

Summers, J.W., Rabinovitch, E.B., 1999. Weatherability of Vinyl and Other Plastics.

Weathering of Plastics. pp. 61-68.

Syakti, A.D., Bouhroum, R., Hidayati, N.V., Koenawan, C.J., Boulkamh, A., Sulistyo, I.,Lebarillier, S., Akhlus, S., Doumenq, P., Wong-Wah-Chung, P., 2017. Beach macro-litter monitoring and floating microplastic in a coastal area of Indonesia. Mar. Pollut. Bull. 122, 217-225.

yakti, A.D., Hidayati, N.V., Jaya, Y.V., Siregar, S.H., Yude, R., Suhendy, Asia, L., Wong Wah-Chung, P., Doumenq, P., 2018. Simultaneous grading of microplastic size sampling in the Small Islands of Bintan water, Indonesia. Mar. Pollut. Bull. 137, 593-600.

Syakti, A.D., Jaya, Y.V., Rahman, A., Hidayati, N.V., Raja'i, T.S., Idris, F., Trenggono, M., Doumenq, P., Chou, L.M., 2019. Bleaching and necrosis of staghorn coral (Acropora

formosa) in laboratory assays: Immediate impact of LDPE microplastics. Chemosphere 228, 528-535

Zielinski, S., Botero, C.M., Yanes, A., 2019. To clean or not to clean? A critical review of

beach cleaning methods and impacts. Mar. Pollut. Bull. 139, 390-401.

Zhao, S., Zhu, L., Li, D., 2015. Characterization of small plastic debris on tourism beaches around the South China Sea. Reg. Stud. Mar. Sci. 1, 55-62. 